\title{
DILEMA KEBEBASAN HAKIM DALAM MENJATUHKAN PIDANA MINIMUM KHUSUS
}

\author{
Dedy Muchti Nugroho \\ Wakil Ketua Pengadilan Negeri Muaro Jambi, Jambi \\ Email : doktordedy@gmail.com
}

\begin{abstract}
Abstrak
Dalam praktik persidangan mengenai independensi kekuasaan kehakiman dalam hal menyangkut kebebasan hakim di dalam memertimbangkan dan memutus perkara pidana di luar KUHP ternyata tidak berjalan penuh sebagaimana mestinya seperti yang diamanatkan undang-undang, landasan teori, dan ketentuan hukum internasional. Hal tersebut terjadi karena pembuat undang-undang sekarang ini mempunyai kecenderungan agar di dalam setiap peraturan perundang-undangan yang dibuatnya terutama yang berkaitan dengan undangundang yang mengandung sanksi pidana selalu memuat dan mencantumkan ketentuan sanksi pidana minimum yang notabene harus dipenuhi dan dijatuhkan hakim di dalam menjatuhkan putusan.

Untuk melaksanakan fungsi yudisial maka pelaksanaan tugas dilakukan oleh hakim selaku pejabat peradilan negara yang mempunyai wewenang untuk mengadili perkara. Meskipun memiliki kemerdekaan yudisial, namun dalam melaksanakan tugasnya hakim selaku pejabat negara bertanggung jawab untuk menegakkan hukum dan keadilan berdasarkan Pancasila, sehingga putusannya mencerminkan rasa keadilan rakyat Indonesia.
\end{abstract}

Kata Kunci : Kebebasan Hakim, Pidana Minimum Khusus

\section{A. Pendahuluan}

Secara umum pendekatan teoritis tentang independensi kekuasaan kehakiman meliputi ajaran kepastian hukum, keadilan hukum dan ajaran hakim sebagai pemberi keadilan yaitu :

Ajaran kepastian hukum, ajaran ini ditegakkan berlandaskan doktrin yang mengajarkan Supremasi Legislatif dalam model sistem trias politica, dimana parlemen diberi wewenang penuh untuk menetapkan semua kebijaksanaan negara dan pemerintah. Setiap kebijakan parlemen sudah mengantisipasi perubahan sosial masyarakat, memperbaharui, menyederhanakan dan memodifikasi hukum melalui jalur formal dalam bentuk kodifikasi atau perubahan hukum. 
Berlandaskan ajaran ini hakim tidak mempunyai wewenang untuk menilai undang-undang dan diciptakan patokan yang membatasi otonomi kebebasan hakim. Oleh karena itu undang-undang tidak bisa diusik dan dipertanyakan hakim pada saat menerapkannya dalam kasus konkret (law made by parliament are supreme, and cannot be questioned in the court). Hakim atau pengadilan harus memutus kasus yang dihadapinya, sesuai dengan syarat-syarat yang ditentukan oleh undang-undang, ajaran ini bersifat positivistik dan legal formal.

Ajaran keadilan hukum, ajaran ini didasarkan pada doktrin hakim berkuasa membentuk hukum Judge Made Law, ajaran ini tercipta oleh karena adanya beberapa alasan kuat yang mendasarinya yaitu di antaranya undang-undang bersifat konservatif dalam artian tidak selalu dapat mengikuti perubahan sosial kemasyarakatan yang terus berjalan kemudian alasan tidak ada satupun undangundang yang sempurna, sehingga untuk mengimbangi dan menghadapi kondisi tersebut adalah tugas dan wewenang hakim untuk mengaktualkan penerapan undang-undang yang dibuat parlemen agar berlaku sebagai living law dan hakim tidak berdiam diri, namun diberi kebebasan untuk menemukan hakikat dan makna sebenarnya dengan cara penafsiran sesuai kondisi perkembangan sosial.

Ajaran hakim sebagai pemberi keadilan, ajaran ini berangkat dari pemikiran adil tidaknya suatu undang-undang berada di tangan hakim. Teori ini menolak supremasi legislatif berdasarkan kenyataan setelah legislatif selesai membuat undang-undang, maka tugas legislatif selesai dan tanggung jawab penerapan undang-undang beralih kepada hakim. Ajaran ini bersifat realisme hukum dan mengkritisi terhadap aliran positivisme yang membungkam kebebasan hakim semata corong undang-undang.

Dalam praktik persidangan mengenai independensi kekuasaan kehakiman dalam hal menyangkut kebebasan hakim di dalam memertimbangkan dan memutus perkara pidana di luar KUHP ternyata tidak berjalan penuh sebagaimana mestinya seperti yang diamanatkan undang-undang, landasan teori dan ketentuan hukum internasional. Hal tersebut terjadi karena pembuat undang-undang sekarang ini mempunyai kecenderungan agar di dalam setiap peraturan 
perundang-undangan yang mengandung sanksi pidana selalu mencantumkan sanksi pidana minimum.

Keterbatasan hakim tersebut akan terasa terutama apabila di persidangan berdasarkan fakta konkrit, hakim memertimbangkan bahwa beban kesalahan yang dilakukan terdakwa pada saat melakukan delik kejahatan ternyata relatif lebih ringan daripada sanksi pidana yang akan diterapkan atas kejahatan itu sendiri sebagaimana diatur dalam undang-undang yang berlaku. Contoh terhadap kasus narkotika, berdasarkan fakta di persidangan ternyata terdakwa adalah seorang pecandu shabu-shabu yang memiliki, menguasai atau membeli shabu sebanyak 0,2 (nol koma dua) gram untuk kepentingan diri sendiri bukan untuk orang lain atau dijual, adalah kurang tepat dan adil apabila diterapkan letterlijk kaku Tuntutan Penuntut Umum yang menjerat dengan dakwaan alternatif Pasal 112 ayat (1) Undang-Undang Nomor 35 Tahun 2009 Tentang Narkotika yang memiliki ancaman pidana penjara minimal 4 (empat) tahun penjara dan pidana denda minimal 800 juta rupiah atau menerapkan ketentuan Pasal 114 ayat (1) dengan ancaman pidana penjara minimal 5 (lima) tahun dan pidana denda minimal 1 milyar rupiah.

Apabila hakim berpendapat berdasarkan pertimbangan keyakinannya secara yuridis, filosofis dan sosiologis untuk menjatuhkan putusan lebih ringan terhadap terdakwa akan langsung berbenturan dengan pembatasan minimum pidana yang ternyata lebih tinggi dari beban kejahatan yang dilakukan terdakwa. Dalam beberapa penelitian yang dilakukan penulis, mayoritas hakim akhirnya mengambil risiko terkecil bagi dirinya dari eksaminasi putusan dan praduga miring masyarakat dengan menghukum terdakwa lebih berat daripada kesalahan yang dilakukannya. Selain itu, kasus di atas bisa terjadi sebaliknya apabila di persidangan terbukti bahwa kejahatan yang dilakukan terdakwa melebihi batas oleh karena di antaranya terdakwa residivis meskipun barang buktinya di bawah 5 (lima) gram, maka hakim memandang bahwa terdakwa patut dijatuhi hukuman berat, namun terganjal pembatasan pidana maksimum undang-undang.

Dari contoh kasus tersebut, seakan terdakwa sudah diputus dan dijatuhi hukuman oleh pembuat undang-undang (legislatif) tanpa memerhatikan fakta- 
fakta persidangan (judex facti) yang dapat dijadikan dasar memberatkan atau meringankan terdakwa. Terhadap hal tersebut sebaiknya kita menyitir dan memahami pendapat filofosis Leo Polak yang mengemukakan bahwa salah satu syarat dalam pemberian pidana adalah beratnya harus seimbang dengan beratnya delik, beratnya pidana tidak boleh melebihi beratnya delik, hal ini perlu agar penjahat tidak dipidana secara tidak adil. ${ }^{12}$

\section{B. Permasalahan}

Berdasarkan latar belakang tersebut, maka permasalahan dalam artikel ini, yaitu :

1 Apakah sebenarnya esensi kebebasan hakim ?

2 Bagaimana latar belakang timbulnya pidana minimum khusus dalam hukum positif di Indonesia?

\section{Pembahasan}

\section{Esensi Kebebasan Hakim Dalam Perspektif Realisme Hukum dan Hukum Progresif}

Penulis mengambil pisau pemecahan permasalahan dengan mengambil analisa teori hukum realisme hukum Amerika oleh karena teori tersebut dipandang lebih tepat atau setidaknya mendekati kesinkronan permasalahan yang dihadapi di dalam menghadapi pemberlakuan sanksi pidana minimum yang tersebar dalam berbagai peraturan pidana di Indonesia.

Berdasarkan aliran Realisme Amerika yang ditokohi Hakim Agung Amerika Serikat, Oliver Wendell Holmes dimulailah titik tolak perubahan dalam praktik persidangan di pengadilan. Aliran tersebut memandang bahwa kebenaran sejati lebih bisa diraih dan dipahami dengan menempatkan empirisme sentuhan pragmatisme yaitu sikap hidup yang menekankan aspek manfaat dan kegunaan berdasarkan pengalaman atau kehidupan nyata. Dalam praktik persidangan dan memecahkan kasus-kasus di pengadilan terutama kasus yang berat maka “kepeloporan para hakim" yang merupakan kelakuan aktual para hakim (pattern

\footnotetext{
${ }^{12}$ Djoko Prakoso dan Nurwachid, Studi tentang Pendapat-Pendapat Mengenai Efektivitas Pidana Mati di Indonesia, Ghalia Indonesia, Jakarta, 2013, hlm.20.
} 
of behaviour) dalam memertimbangkan fakta-fakta di persidangan sebenarnya merupakan hal yang utama dan penting, jadi bukan hanya aturan tertulis saja yang harus dipahami dan dijadikan pedoman semata dalam memutus suatu perkara. Jadi dengan kepeloporan hakim menerapkan hukum yang tidak tertulis dan faktor-faktor lain seperti ekonomi, sosial, budaya, psikologi dan moral hidup pribadi hakim melalui metode penafsiran dan konstruksi hukum dimungkinkan hakim memiliki kompetensi mengubah dan menerobos aturan pidana minimum khusus.

Kebenaran riil bukan terletak dalam undang-undang, namun pada kenyataan hidup. Inilah titik tolak teori tentang kebebasan hakim yang diusung oleh Oliver Wendell Holmes dan Jerome Frank (eksponen realisme hukum Amerika). Hukum yang termuat dalam aturan-aturan, hanya suatu generalisasi mengenai dunia ideal. Menurut Holmes, seorang pelaksana hukum (hakim) sesungguhnya menghadapi gejala-gejala hidup secara realistis. ${ }^{13}$

Aturan hukum, di mata Holmes, hanya menjadi salah satu faktor yang patut dipertimbangkan dalam putusan yang "berbobot", faktor moral, kemanfaatan dan keutamaan kepentingan sosial, misalnya menjadi faktor yang tidak kalah penting dalam mengambil pertimbangan bagi putusan "berkualitas". Jadi bukan sebuah pantangan, jika demi putusan yang kontekstual, aturan resmi terpaksa disingkirkan. Holmes menjadi hakim yang monumental, kreatif dan memiliki pengaruh besar, justru karena pendirian moralnya. ${ }^{14}$

Jerome Frank dalam tulisannya "Law and The Modern Mind" menegaskan bahwa hukum harus selalu ditemukan, karena apabila hakim dalam memutuskan perkara hanya didasarkan undang-undang sesungguhnya hakim menipu dirinya dengan menyembunyikan fakta bahwa tiap-tiap perkara berbeda jenis fakta hukum dan menuntut suatu putusan berbeda pula. Frank juga menyatakan bahwa dalam mengambil putusan hakim dipengaruhi faktor politik, ekonomi, moral, simpati dan antipati, namun itu semua hanya sekedar dijadikan pertimbangan. ${ }^{15}$

\footnotetext{
13 Ibid, hlm.150.

${ }^{14}$ Ibid, hlm.152.

15 Jerome Frank, Law and The Modern Mind, Hukum dan Pemikiran Modern, Nuansa Cendekia, Jakarta, 2017, hlm.76.
} 
Satjipto Rahardjo, mencetuskan gagasan hukum progresif telah menawarkan perspektif, spirit, dan cara baru mengatasi "kelumpuhan hukum" di Indonesia sebagai akibat dari pengaruh positivisme yang dominan. Ajaran hukum progresif telah memasuki lapangan pemikiran dan tindakan di dalam penegakan hukum di Indonesia. Progresif berasal dari kata progress yang berarti kemajuan, hukum hendaknya mampu mengikuti dan menjawab perubahan jaman serta mampu melayani masyarakat dengan menyandarkan aspek moralitas dari sumber daya manusia penegak hukum. Satjipto Rahardjo kemudian berkesimpulan bahwa salah satu penyebab menurunnya kinerja dan kualitas penegak hukum di Indonesia adalah dominasi paradigma positivisme dengan sifat formalitasnya yang mengharuskan aparat penegak hukum melaksanakan ketentuan hukum kaku dan terbatas sebagaimana tercantum dalam perundang-undangan yang berlaku. ${ }^{16}$

Menghadapi adanya pembatasan minimum pemidanaan dalam suatu undang-undang yang menurut penulis cenderung positivistik, maka sudah seharusnya hakim sebagai aparat penegak hukum progresif tidak langsung harus menepis keberadaan aturan tersebut. Hakim dapat melakukan interpretasi baru terhadap aturan untuk memberi keadilan dan kebahagiaan pencari keadilan. Hukum bukan hanya bangunan peraturan, melainkan juga bangunan ide, kultur dan cita-cita. Satjipto Rahardjo mengingatkan bahwa letak persoalan hukum adalah pada manusia bukan hanya hukum semata.

Paradigma hukum progresif, bahwa hukum adalah untuk manusia. Pegangan optik atau keyakinan dasar tidak melihat hukum sebagai suatu sentral dalam berhukum, melainkan manusia yang berada di titik pusat perputaran hukum. Hukum berputar di sekitar manusia sebagai pusatnya. Hukum ada untuk manusia, bukan manusia untuk hukum. Oleh karena itu, apabila hukum tidak memihak kepada kebahagiaan manusia maka hukum dapat dikesampingkan, yang dalam praktik persidangan dilakukan hakim selaku pejabat negara yang memiliki diskresi untuk "menyimpangi" aturan yang ada demi keadilan, kepastian dan kemanfaatan hukum itu sendiri.

\footnotetext{
16 Satjipto Rahardjo, Op.cit, hlm.46.
} 


\section{Latar Belakang Adanya Pidana Minimum Khusus di Indonesia}

KUHP yang menjadi induk dari peraturan perundang-undangan pidana di Indonesia, selain mengatur pidana maksimum (umum maupun khusus) juga mengatur pidana minimum, yaitu minimum untuk pidana penjara adalah 1 (satu) hari (Pasal 12 ayat (2) KUHP dan minimum untuk pidana kurungan adalah 1 (satu) hari (Pasal 18 ayat (1) KUHP). Terkait dengan pidana minimum di luar yang umum tersebut (in casu pidana minimum khusus) ternyata KUHP sama sekali tidak mengaturnya. Tidak ada ketentuan di dalam aturan umum (general rules) KUHP yang mengatur tentang ketentuan-ketentuan dasar yang harus diperhatikan apabila pembuat undang-undang di luar KUHP ingin mengatur tentang pidana minimum khusus tersendiri yang menyimpang dari pidana minimum umum KUHP tersebut.

Dalam praktik, pencantuman pidana minimum khusus menimbulkan permasalahan baru, oleh karena pidana minimum khusus akan berbenturan dengan kebebasan hakim di dalam menjatuhkan vonis dan semata hanya sebagai corong undang-undang, terutama apabila di persidangan dijumpai fakta-fakta yang meringankan dari delik yang dilakukan oleh terdakwa, selain itu pemberlakuan pidana minimum khusus yang tersebar di beberapa undang-undang yang ada ternyata tidak dibarengi dengan pedoman pemidanaan yang mengatur pidana minimum khusus di dalam setiap ketentuannya, hanya sedikit yang mencantumkan pedoman pemidanaan minimum khusus di antaranya UndangUndang Nomor 35 Tahun 2009 tentang Narkotika (Bab XV) dan Undang-Undang Nomor 31 Tahun 1999 jo Undang-Undang Nomor 20 tahun 2001 Tentang Pemberantasan Tindak Pidana Korupsi (Pasal 12 A).

Tidak adanya formulasi tentang pedoman pemidanaan pada kebanyakan undang-undang khusus di luar KUHP yang mencantumkan pidana minimum khusus dalam rumusan delik, pada gilirannya berpotensi menimbulkan masalah yuridis di tingkat aplikasi. Setidaknya ketika hakim yang mengadili perkara pidana yang bersangkutan ternyata di persidangan dihadapkan pada fakta hukum banyaknya faktor-faktor yang dapat meringankan pidana yang melekat pada 
terdakwa, maka hakim harus mempertaruhkan profesinya untuk "menerobos" aturan pidana minimum yang berlaku atas dasar keadilan.

Hal tersebut berbeda dengan Rancangan KUHP Nasional yang mengatur ancaman pidana minimal khusus disertai aturan/pedoman pemidanaan atau penerapannya (Pasal 66, 82, 120, 121, 130, 137) sehingga dapat dijadikan patokan oleh penegak hukum dalam praktik persidangan. ${ }^{17}$

Tidak adanya pedoman pemidanaan minimum khusus tersebut menjadi realitas dalam praktik di Indonesia. Artinya, meskipun di dalam rumusan deliknya sudah secara eksplisit ditentukan pidana minimum khususnya, namun dengan argumentasi hukum tertentu, tetap saja batas limit pidana minimum khusus tersebut ditabrak. Problem yuridis yang kemudian muncul adalah adanya friksi kepastian hukum (rechtszekerheid) di satu pihak dengan keadilan hukum (gerechtigheid) di lain pihak.

Dalam hal ini perlu dicermati bahwa timbulnya pidana minimum khusus di Indonesia tidak terlepas dari berkembangnya isu sosial dan penegakan hukum yang berlaku membutuhkan kebijakan pidana sebagai bagian dari pembaharuan hukum pidana yang diakomodir oleh pembuat undang-undang secara langsung, meskipun belum tentu kebijakan tersebut dapat bermanfaat dan menyentuh rasa keadilan dan kepastian hukum di masyarakat oleh karena dilandasi oleh pandangan politik hukum semata.

Pembaharuan hukum pidana menurut Barda Nawawi Arief, ${ }^{18}$ pada hakikatnya harus ditempuh dengan pendekatan yang berorientasi pada kebijakan dan sekaligus pendekatan yang berorientasi pada nilai. Dilihat dari sudut pendekatan kebijakan yaitu :

1. Sebagai bagian dari kebijakan sosial,pembaharuan hukum pidana pada hakikatnya merupakan bagian dari upaya untuk mengatasi masalah-masalah sosial.

${ }^{17}$ Dwidja Prijatno, Jenis-Jenis Sanksi (Pidana) dalam Konsep RUU KUHP Nasional (ditinjau dari filsafat pemidanaan), Makalah, UNS Surakarta, 2016, hlm.14.

18 Barda Nawawi Arief, Bunga Rampai Kebijakan Hukum Pidana, Prenada Media Group, Jakarta, 2008, hlm.29. 
2. Sebagai bagian dari kebijakan kriminal, pembaharuan hukum pidana pada hakikatnya merupakan bagian dari upaya perlindungan masyarakat.

3. Sebagai bagian dari kebijakan penegakan hukum, pembaharuan hukum pidana pada hakikatnya merupakan bagian dari upaya memperbaharui sistem hukum.

Dilihat dari sudut pendekatan nilai pembaharuan hukum pidana mengandung makna, suatu upaya untuk melakukan reorientasi dan reformasi hukum pidana yang sesuai dengan nilai-nilai sentral sosio-politik, sosio-filosofis dan sosio-kultural masyarakat Indonesia yang melandasi dan memberi isi terhadap muatan normatif dan substantif hukum pidana yang dicita-citakan.

Selain itu, pidana minimum khusus diberlakukan di Indonesia oleh karena adanya perkembangan baik secara kualitas ataupun kuantitas dari kejahatan yang berlaku baik secara lokal maupun global yang dipandang sifatnya sudah sangat tercela, maka ancaman hukumannya diperberat oleh pembentuk undang-undang, yaitu perilaku yang mengakibatkan terjadinya kegoncangan dalam masyarakat, seperti penganiayaan, kejahatan terhadap jiwa, integritas jiwa dan raga maupun kebebasan manusia ${ }^{19}$.

Menurut Muladi, dengan memperhitungkan berbagai kepentingan yang terkait dengan penegakan hukum pidana, maka nampak adanya kecenderungankecenderungan internasional yang salah satunya adalah dengan mengembangkan sanksi (pidana) maksimum khusus untuk kejahatan-kejahatan tertentu. Pengembangan pidana minimum khusus tersebut adalah dalam rangka mengurangi disparitas pidana (disparity of sentencing) dan menunjukkan beratnya tindak pidana yang dilakukan ${ }^{20}$.

Disparitas pidana adalah penerapan pidana yang tidak sama terhadap tindak-tindak pidana yang sama atau terhadap tindak pidana yang sifatnya

19 Loebby Loeqman, Pidana dan Pemidanaan, Datacom, Jakarta, 2017, hlm 18.

20 Muladi, Hak Asasi Manusia, Politik dan Sistem Peradilan Pidana, Undip Press, Semarang, 2002, hlm.154. 
berbahaya yang dimilikinya dapat diperbandingkan tanpa dasar pembenaran yang jelas $^{21}$.

Seiring dengan uraian di atas, maka dianutnya sistem ancaman minimum khusus yang selama ini tidak dikenal dalam KUHP didasarkan pada pokok pemikiran $^{22}$ :

1. Untuk menghindari adanya disparitas pidana yang sangat mencolok untuk delik-delik yang secara hakiki tidak berbeda kualitasnya.

2. Untuk lebih mengefektifkan prevensi general, khususnya bagi delik-delik tertentu yang dipandang membahayakan dan meresahkan masyarakat.

3. Adanya keinginan untuk memenuhi tuntutan masyarakat yang menghendaki adanya standar minimal objektif bagi delik yang membahayakan masyarakat dan negara.

4. Dianalogikan dengan pemikiran, bahwa apabila dalam hal-hal tertentu maksimum pidana (umum maupun khusus) dapat diperberat, maka minimum pidana pun hendaknya dapat diperberat dalam hal-hal tertentu.

Apabila dihubungkan dengan salah satu tujuan utama pemidanaan, yaitu mencegah atau pelaku pelaku tindak pidana tersebut dan juga orang-orang lain yang mungkin mempunyai maksud untuk melakukan kejahatan semacam itu, maka pokok pemikiran kedua dianutnya pidana minimum khusus (prevensi general) dalam Konsep KUHP sudah sejalan dengan tujuan pemidanaan.

Adalah benar, hakim bukan mulut atau corong undang-undang (bouche de la loi atau spreekbuis van de wet). Hakim juga tidak boleh dipasung dengan rumusan perundang-undangan yang terasa rijid dan kaku / keras, ketika dihadapkan pada fakta banyaknya faktor-faktor yang meringankan yang dilandasi keadilan. Misalnya faktor meringankan yang terkait dengan perbuatannya (percobaan atau pembantuan) dan yang terkait dengan orangnya (misalnya tindak pidana yang dilakukan oleh wanita hamil, atau dilakukan karena kegoncangan jiwa, keterbelakangan mental), dan terkait dengan korban (misalnya, adanya

\footnotetext{
${ }^{21}$ Muladi dan Barda Nawawi Arief, Teori-Teori dan Kebijakan Hukum Pidana, Alumni, Bandung, 1998, hlm. 52.

${ }_{22}$ Barda Nawawi Arief, Bunga Rampai Kebijakan Hukum Pidana, Op.Cit, hlm. 125.
} 
pemberian ganti kerugian yang layak atau perbaikan terhadap kerusakan secara sukarela sebagai akibat tindak pidana yang dilakukan).

Menjadi menarik apa yang pernah diingatkan oleh Herbert L. Packer, bahwa penggunaan sanksi pidana secara sembarangan atau menyamaratakan pemberian sanksi pidana (indiscriminately) serta digunakan pemberlakuan sanksinya secara paksa (coercively) terhadap terdakwa, justru akan menyebabkan sarana pidana itu menjadi suatu pengancam utama (prime threatener) terhadap nilai-nilai kemanusiaan dan keadilan ${ }^{23}$.

Mencermati identifikasi masalah tersebut mengenai tindakan apakah yang dapat dilakukan oleh hakim ketika akan menjatuhkan vonis ternyata berhadapan dengan adanya pembatasan pemidanaan berupa pidana minimum khusus, sedangkan hakim mempunyai pertimbangan yuridis tersendiri yang lebih ringan atau sebaliknya sama terhadap pidana yang dijatuhkan. Terhadap masalah tersebut, maka menurut ajaran realisme hukum Amerika terutama dikaitkan dengan pemikiran Oliver Wendell Holmes dapat ditempuh pemecahan masalah yaitu bahwa hukum pada dasarnya adalah kelakuan aktual para hakim (patterns of behaviour) yang diperoleh selama proses persidangan berlangsung, dimana kelakuan itu ditentukan oleh tiga faktor sebagai hal yang dapat secara nyata mempengaruhi hakim di dalam menjatuhkan putusan, yaitu kaidah hukum yang dikonkretkan oleh hakim melalui metode interpretasi dan kontruksi, moral hidup pribadi hakim, dan kepentingan sosial yang dihadapi.

Adanya 3 (tiga) faktor tersebut Holmes secara langsung telah memberikan solusi pemecahan masalah terhadap positivistik yang terjadi yaitu hakim dapat melakukan tindakan yang bertentangan dengan peraturan yang berlaku sepanjang 3 (tiga) faktor yang merupakan patokan di atas tidak dilanggar, terutama solusi permasalahan melalui penerapan metode interprestasi dan konstruksi hukum.

Sehingga dengan adanya 3 (tiga) faktor sebagai patokan solusi pemecahan masalah hakim dalam praktek persidangan, maka adanya ketentuan pidana minimum khusus yang berlaku dalam banyak peraturan perundang-undangan di

23 Herbert L. Packer, The Limits of The Criminal Sanction, Indiana Law Journal, 2011, Vol.44. 
Indonesia sebagai kaidah normatif yang terpatenkan dan juga dipandang sebagai bagian kebijakan perubahan bidang hukum pidana yang terjadi dalam skala kecil, yang tidak berhubungan langsung dengan politik hukum pemerintah atau negara (publik) tetapi hanya sebagai pembaharuan (law as tool as social enginnering) semata dalam bidang peraturan hukum yang berlaku dalam skala perundangundangan dapat diterobos sepanjang berguna untuk keadilan justiabelen itu sendiri. $^{24}$

Oliver Wendels Holmes dan Jerome Frank, menentang pendapat bahwa hukum yang ada itu lengkap dan dapat dijadikan sumber bagi hukum untuk memutuskan dalam peristiwa yang konkret. Pelaksanaan undang-undang oleh hakim bukan semata-mata merupakan persoalan logika dan penggunaan pikiran yang tepat saja, tetapi lebih merupakan pemberian bentuk yuridis kepada asas-asas hukum materiil yang menurut sifatnya tidak logis dan lebih mendasarkan kepada pengalaman dan penilaian yuridis daripada mendasarkan kepada akal yang abstrak ${ }^{25}$.

Hakim mengadili suatu perkara yang dipentingkan adalah fakta atau peristiwa, dan bukan hukumnya dimana peraturan hukum hanyalah alat semata, peristiwa kongkret dapat diperoleh berdasarkan hasil pembuktian jawab menjawab dipersidangan, sehingga setelah peristiwa konkret dapat dikonstatir adanya atau terjadinya kemudian baru dicarikan hukumnya, manakala undang-undang tidak lengkap, tidak jelas, atau kurang memberikan rasa keadilan, maka hakim harus menemukan hukumnya (rechtsvinding),

\section{Kesimpulan}

1. Kebebasan hakim berdasarkan aliran realisme hukum Amerika yang dipelopori oleh tokoh-tokohnya diantaranya Oliver Wendell Holmes, Jerome Frank, Benjamin Cardozo, dikaitkan dengan hukum progesifnya Satjipto Rahardjo dapat disinergikan bahwa kebebasan hakim harus dipertahankan dan dihormati keberadaanya di dalam menjatuhkan putusan oleh karena

\footnotetext{
${ }^{24}$ Donny Danardono, Wacana Pembaharuan Hukum di Indonesia, Ford Foundation \& Huma, Jakarta, 2017, hlm. 94.

${ }^{25}$ Ahmad Rifai, Penemuan Hukum Oleh Hakim dalam Perspektif Hukum Progresif, Sinar Grafika, Jakarta, 2010, hlm.25.
} 
kebenaran yang rill bukan terletak semata-mata dalam undang-undang saja yang berlaku secara positifistik dan kaku, akan tetapi pada kenyataan hidup yang terjadi di masyarakat secara riil, hakim mempunyai kebebasan dan kewenangan untuk menemukan hukumnya sendiri atas dasar kepentingan umum dan hukum yang mengabdi untuk dan demi kebahagiaan manusia itu sendiri.

2. Latar belakang timbulnya pidana minimum khusus di Indonesia adalah sebagai wujud kebijakan pembaharuan hukum pidana yang berlandaskan pandangan politik hukum, timbul sebagai akibat kurangnya kepercayaan publik terhadap lembaga pengadilan, untuk menghindari dan mengantisipasi adanya disparitas pidana dalam putusan, prevensi general terhadap kejahatan berat yang terjadi di masyarakat, dan analogi terhadap adanya pidana maksimum. Bahwa menurut Oliver Wendell Holmes, Jerome Frank dan Satjipto Rahardjo, kebebasan hakim adalah sesuatu yang prinsipil dan berlaku universal. Oleh karena itu, hakim tidak mutlak harus selalu menjadi corong undang-undang yang kaku, prosedural, dan legal formal semata, akan tetapi hakim dapat menyimpangi ketentuan undang-undang yang berlaku dengan landasan hukum yang jelas di antaranya dapat melakukan "menerobos" ketentuan undang-undang seperti halnya pembatasan minimum khusus pidana melalui upaya-upaya penemuan hukum (rechtsvinding) dan penciptaan hukum (rechtsschepping) dengan melalui cara interprestasi dan konstruksi hukum. 


\section{DAFTAR PUSTAKA}

Abdullah, 2015, Pertimbangan Hukum Putusan Pengadilan, Sidoarjo : Program Pascasarjana Universitas Sunan Giri.

Abdul Manan, 2015, Aspek-Aspek Pengubah Hukum, Jakarta : Kencana. , 2015, Penerapan Hukum Acara Perdata di Lingkungan Peradilan Agama, Jakarta : Kencana.

Abdul Mukhtie Fadjar, 2001, Peran "The Rule of Law” Dalam Penguatan "Civil Society" Dalam IDEA Kumpulan Makalah "Konstitusi dan Demokrasi", Jakarta : IDEA.

Abdulkadir Muhammad, 2015, Etika Profesi Hukum, Bandung : Citra Aditya Bakti.

Aditya Bakti.

2016, Hukum Acara Perdata Indonesia, Bandung : Citra

Achmad Ali, 2011, Menjelajahi Kajian Empiris Terhadap Hukum, Jakarta : Yarsif Watampone. ,2010, Tujuan dan Fungsi Hukum, Jakarta : Ghalia Indonesia.

Ade Saptomo, 2010, Hukum dan Kearifan Lokal, Revitalisasi Hukum Adat Nusantara, Jakarta : Raja Grafindo Persada.

Adi Sulistiyono, 2006, Krisis Lembaga Peradilan Indonesia, Surakarta : Lembaga Pengembangan Pendidikan (LPP) Universitas Sebelas Maret dan UPT Penerbitan dan Percetakan Universitas Sebelas Maret (UNS Press). , 2004, Menggugat Dominasi Positivisme Dalam Ilmu Hukum, Surakarta : Sebelas Maret University Press.

Adian Donny Gahral, 2015, Arus Pemikiran Kontemporer, Yogyakarta : Jalasutra.

Adriaan W. Bedner, 2012, Suatu Pendekatan Elementer Terhadap Negara Hukum, dalam Sulistyowati Irianto dkk (ed), Kajian Sosio-Legal, Denpasar, Pustaka Larasan.

Ahmad Kamil, 2012, Filsafat Kebebasan Hakim, Jakarta : Prenada Media Utama.

Ahmad Rifai, 2015, Penemuan Hukum Oleh Hakim dalam Perspektif Hukum Progresif, Jakarta : Sinar Grafika. 
Aji Samekto, 2015, Hukum Kritis Kritik Terhadap Hukum Modern, Bandung : Citra Aditya Bakti.

,2008, Justice Not for All, Kritik Terhadap Hukum Modern Dalam Perspektif Studi Hukum Kritis, Yogyakarta : Genta Press.

Aloysius Wisnusubroto,1997, Hukum dan Pengadilan di Indonesia, Yogyakarta : Unika Atma Jaya.

Allan Ryan, 1999, Justice in Politics and Government, Oxford : Oxford University Press.

Alimandan, 2011, Sosiologi Ilmu Pengetahuan Berparadigma Ganda, Jakarta : Raja Grafindo Persada.

Altman, Andrew, 2015, Critical Legal Studies, A Liberal Critique, New Jersey : Priceton University Press.

Allot, Anthony, 2014, The Limits of Law, London : Butterworths \& Co.

Antonius Cahyadi dan E. Fernando Manulang, 2007, Pengantar Filsafat Hukum, Jakarta : Fajar Interpratama Offset.

Antonius Sudirman, 2016, Hati Nurani Hakim dan Putusannya Suatu Pendekatan dari Perspektif Ilmu Hukum Perilaku (Behavioral Jurisprudence) Kasus Bismar Siregar, Bandung : Citra Aditya Bakti.

Antonin Scalia and Bryan A. Garner, 2012, Reading Law : The Interpretation of Legal Text, United States of America : Thomson - West.

Anthon F. Susanto, 2015, Wajah Peradilan Kita Konstruksi Sosial tentang Penyimpangan, Mekanisme Kontrol dan Akuntabilitas Peradilan Pidana, Bandung : Refika Aditama.

Arbijoto, 2009, Kebebasan Hakim (Refleksi Terhadap Manusia Sebagai Homo Religious), Jakarta : Mahkamah Agung Republik Indonesia.

Artidjo Alkostar, 2013, Negara Tanpa Hukum Catatan Pengacara Jalanan, Yogyakarta : Pustaka Pelajar.

Bagir Manan, 2015, Dasar-dasar Perundang-undangan Indonesia, Jakarta : IndHill-Co. 